\title{
COMMENTARY
}

\section{The dichotomy of inhibiting nuclear factor kappa-B in pneumonia}

\author{
Edward Abraham* \\ See related research by Devaney et al., http://ccforum.com/content/17/2/R82
}

\begin{abstract}
Activation of nuclear factor kappa-B (NF-kB) results in its translocation from the cytoplasm to the nucleus and binding to the promoters of a large number of genes, including those encoding proinflammatory cytokines and other mediators that can contribute to organ system dysfunction in severe infection. While inhibition of NF-KB activation has been proposed as a therapeutic approach in critical illness, several studies have indicated that such an approach may have deleterious effects in persistent infectious states, such as pneumonia. A new report from Devaney and colleagues shows that while inhibition of NF-KB may be useful in severe pneumonia associated with rapid progression to mortality, it leads to worsened pulmonary injury with increased bacterial numbers in the lungs in a model of prolonged pneumonia. Such data raise concerns about therapeutic approaches targeting NF-KB in critically ill patients with persistent infection.
\end{abstract}

Binding sites for the transcriptional regulatory factor nuclear factor kappa-B (NF- $\mathrm{kB}$ ) are found in the promoters of many immunoregulatory genes whose expression plays a central role in acute inflammation and critical illness $[1,2]$. For example, NF- $\mathrm{kB}$ is involved in the transcription of genes encoding proinflammatory cytokines, such as IL- 8 and TNF- $\alpha$, adhesion molecules, including intracellular adhesion molecule 1 (ICAM-1), molecules involved in regulation of apoptosis, such as $\mathrm{B}$ cell lymphoma 2 (Bcl-2), and growth factors, such as erythropoietin. Activation of NF-kB, with increased translocation from the cytoplasm to the nucleus, is associated with a higher likelihood of mortality in patients with sepsis and acute lung injury $[3,4]$.

*Correspondence: eabraham@wakehealth.edu

Office of the Dean, Wake Forest School of Medicine, Medical Center Boulevard, Winston-Salem, NC 27157, USA
Because of the association between enhanced activation of NF- $\mathrm{kB}$ and poor outcomes in patients with sepsis and acute lung injury, inhibition of NF- $\mathrm{KB}$ has been hypothesized to be beneficial in critical illnesses in which an overly exuberant inflammatory response plays a major role. In preclinical models of sepsis and acute lung injury, and particularly those involving endotoxemia or other insults associated with rapid and large increases in proinflammatory cytokines and other mediators, suppression of NF- $\mathrm{KB}$ activation does indeed result in improved survival [5-7]. However, the benefits of inhibiting NF-kB in more chronic models of critical illness, such as that associated with pneumonia, is less clear. For example, transgenic mice lacking the RelA subunit of NF-kB demonstrate decreased cytokine expression, alveolar neutrophil emigration, and lung bacterial killing during pneumococcal pneumonia [8]. Similarly, in mice with Klebsiella-induced pneumonia, inhibition of NF-kB activation through elimination of the Toll-like receptor adapter protein MyD88 resulted in diminished neutrophil influx into the lungs as well as greater numbers of bacteria in the lungs and enhanced systemic enhanced dissemination of Klebsiella [9]. In Pseudomonas aeruginosa pneumonia, transgenic mice with enhanced NF-kB activation showed greater expression of proinflammatory chemokines, neutrophil influx and bacterial clearance in the lungs, and improved survival. In contrast, mice with diminished NF-KB activation in epithelial cells showed impaired responses to $P$. aeruginosa infection, with higher bacterial colony counts in the lungs and decreased neutrophilic lung inflammation [10].

Devaney and colleagues [1] now present confirmatory evidence that while inhibition of NF- $\mathrm{KB}$ early in severe pneumonia diminishes lung injury and improves survival, suppression of NF-kB activation in less severe and more chronic pneumonia results in greater pulmonary injury and increased numbers of bacteria in the lungs. In this study, suppression of NF- $\mathrm{kB}$ activation was accomplished through using pulmonary gene therapy with adenoassociated virus (AAV) vectors encoding the inhibitor of kappa $B$ alpha (IкB $\alpha$ ) and resulting in overexpression of Iк $\mathrm{B} \alpha$, which diminishes cytoplasmic to nuclear 
translocation of NF- $\mathrm{kB}$. This approach is similar to that used in studies previously reported by Sadikot and colleagues $[11,12]$, in which inhibition of NF-kB was achieved using an adenoviral vector expressing a dominant negative form of $\mathrm{I}_{\kappa} \mathrm{B} \alpha$. Similar to the results in the study of Devaney and colleagues, Sadikot and colleagues found that inhibition of NF- $\mathrm{B}$ resulted in diminished bacterial clearance and inflammatory response in the lungs during $P$. aeruginosa pneumonia.

The acute pneumonia model used by Devaney and colleagues involves exposure of the lungs to high numbers $\left(1 \times 10^{11}\right)$ of Escherichia coli. This model results in the rapid onset of pulmonary inflammation, with most animals dying within 4 hours, and resembles the time course and pathophysiologic and immunologic responses found with intratracheal instillation of lipopolysaccharide. In this acute and highly lethal model of pulmonary inflammation, I $\mathrm{K} \mathrm{B} \alpha$ improved survival. In contrast, in a chronic model of pneumonia, induced by intratracheal injection of 20 -fold fewer E. coli $\left(5 \times 10^{9}\right)$ than with the conditions for acute pneumonia, treatment of mice with the AAV-IKB $\alpha$ construct was associated with greater pulmonary inflammation, as shown by increased levels of the proinflammatory cytokines IL- $1 \beta$ and TNF- $\alpha$, worse histologic evidence of lung injury, and higher bacterial numbers in the lungs.

What are the implications of these studies that investigated the role of NF- $\mathrm{kB}$ activation in pneumonia? Clearly, they demonstrate the importance of a dysregulated, overly intense inflammatory response in inducing pulmonary injury during the early stages of massive bacterial exposure. In addition, these experiments show that an intact inflammatory response, in which NF- $\mathrm{kB}$ plays a major role, is required for appropriate host defense against the later stages of bacterial pneumonia. Such results are consistent with older studies showing that immunosuppression, such as that achieved by corticosteroids [13] or by blockade of proinflammatory mediators, including inhibition of TNF- $\alpha$ [14] or CXC chemokines [15], resulted in increased numbers of bacteria in the lungs and worse outcome from pneumonia. In addition, the experiments reported by Devaney and colleagues and others highlight the danger of broadly inhibiting inflammatory responses in chronic infective states, such as that associated with pneumonia. Identification of patients at high risk of death from inflammation-induced organ dysfunction as well as titration of inflammation in such patients, in terms of both timing of interventions aimed at modulating the inflammatory process and the targeting of specific proinflammatory mediators, will be essential in improving outcome from life-threatening infectious processes associated with critical illness.

\section{Abbreviations}

$A A V$, adeno-associated virus; IKBa, inhibitor of kappa $B$ alpha; IL, interleukin; NF-kB, nuclear factor kappa-B; TNF, tumor necrosis factor alpha.

\section{Competing interests}

The author declares that they have no competing interests.

Published: 11 June 2013

\section{References}

1. Devaney J, Curley GF, Hayes M, Masterson C, Ansari B, O'Brien T, O'Toole D, Laffey JG: Inhibition of pulmonary nuclear factor kappa-B decreases the severity of acute $E$. coli pneumonia but worsens prolonged pneumonia. Crit Care 2013, 17:R82.

2. Hayden MS, Ghosh S: NF-kappaB, the first quarter-century: remarkable progress and outstanding questions. Genes Dev 2012, 26:203-234.

3. Arnalich F, Garcia-Palomero E, Lopez J, Jimenez M, Madero R, Renart J, Vazquez JJ, Montiel C: Predictive value of nuclear factor kappaB activity and plasma cytokine levels in patients with sepsis. Infect Immun 2000, 68:1942-1945.

4. Yang KY, Arcaroli JJ, Abraham E: Early alterations in neutrophil activation are associated with outcome in acute lung injury. Am J Respir Crit Care Med 2003, 167:1567-1574

5. Liu G, Park YJ, Tsuruta Y, Lorne E, Abraham E: p53 Attenuates lipopolysaccharide-induced NF-kappaB activation and acute lung injury. J Immunol 2009, 182:5063-5071.

6. Everhart MB, Han W, Sherrill TP, Arutiunov M, Polosukhin WV, Burke JR, Sadikot RT, Christman JW, Yull FE, Blackwell TS: Duration and intensity of NF-kappaB activity determine the severity of endotoxin-induced acute lung injury. J Immunol 2006, 176:4995-5005.

7. Lancaster LH, Christman JW, Blackwell TR, Koay MA, Blackwell TS: Suppression of lung inflammation in rats by prevention of NF-kappaB activation in the liver. Inflammation 2001, 25:25-31.

8. Quinton $L$, Jones MR, Simms BT, Kogan MS, Robson BE, Skerrett SJ, Mizgerd JP: Functions and regulation of NF-kappaB RelA during pneumococcal pneumonia. J Immunol 2007, 178:1896-1903.

9. Cai S, Batra S, Shen L, Wakamatsu N, Jeyaseelan S: Both TRIF- and MyD88dependent signaling contribute to host defense against pulmonary Klebsiella infection. J Immuno/ 2009, 183:6629-6638.

10. Chen SM, Cheng DS, Williams BJ, Sherrill TP, Han W, Chont M, Saint-Jean L, Christman JW, Sadikot RT, Yull FE, Blackwell TS: The nuclear factor kappa-B pathway in airway epithelium regulates neutrophil recruitment and host defence following Pseudomonas aeruginosa infection. Clin Exp Immunol 2008, 153:420-428

11. Sadikot RT, Zeng H, Joo M, Everhart MB, Sherrill TP, Li B, Cheng DS, Yull FE, Christman JW, Blackwell TS: Targeted immunomodulation of the NF-kappaB pathway in airway epithelium impacts host defense against Pseudomonas aeruginosa. J Immuno/ 2006, 176:4923-4930.

12. Sadikot RT, Han W, Everhart MB, Zoia O, Peebles RS, Jansen ED, Yull FE, Christman JW, Blackwell TS: Selective I kappa B kinase expression in airway epithelium generates neutrophilic lung inflammation. J Immuno/ 2003, 170:1091-1098.

13. Sadikot RT, Jansen ED, Blackwell TR, Zoia O, Yull F, Christman JW, Blackwell TS: High-dose dexamethasone accentuates nuclear factor-kappa b activation in endotoxin-treated mice. Am J Respir Crit Care Med 2001, 164:873-878.

14. Moore TA, Lau HY, Cogen AL, Standiford TJ: Defective innate antibacterial host responses during murine Klebsiella pneumoniae bacteremia: tumor necrosis factor (TNF) receptor 1 deficiency versus therapy with anti-TNFalpha. Clin Infect Dis 2005, 41 Suppl 3:S213-217.

15. Greenberger MJ, Strieter RM, Kunkel SL, Danforth JM, Laichalk LL, McGillicuddy DC, Standiford TJ: Neutralization of macrophage inflammatory protein-2 attenuates neutrophil recruitment and bacterial clearance in murine Klebsiella pneumonia. J Infect Dis 1996, 173:159-165.

doi:10.1186/cc12722

Cite this article as: Abraham E: The dichotomy of inhibiting nuclear factor kappa-B in pneumonia. Critical Care 2013, 17:152. 